\title{
Lactose intolerance, lactose malabsorption and genetic predisposition to adult-type hypolactasia in patients after restorative proctocolectomy
}

\author{
Jarosław Walkowiak1, Ewa Fidler-Witoń1, Aleksandra Glapa1, Jacek Paszkowski², \\ Maciej Borejsza-Wysocki², Anna Miśkiewicz-Chotnicka1, Tomasz Banasiewicz \\ and Aleksandra Lisowska'
}

PPoznań University of Medical Sciences, Department of Paediatric Gastroenterology and Metabolic Diseases, Poznań, Poland; 2Poznań University of Medical Sciences, Chair and Department of General \& Endocrine Surgery, and Gastroenterological Oncology, Poznań, Poland

This study provides up-to-date findings on lactose malabsorption, lactose intolerance and genetic predisposition to adult-type hypolactasia in 72 patients after restorative proctocolectomy (RPC). The lactose malabsorption was assessed by hydrogen-methane breath test. Genetic predisposition to adult-type hypolactasia was assessed by detecting $-13910 \mathrm{~T} / \mathrm{C}$ polymorphism in the lactase gene. Lactose intolerance was more frequent in UC (ulcerative colitis) patients than FAP (familial adenomatous polyposis) patients $(77.5 \%$ vs. $55.2 \% ; p=0.01)$. The $\mathrm{C} / \mathrm{C}$ genotype of the lactase gene was observed in $39.1 \%$ subjects with no significant difference between UC and FAP patients. Lactose malabsorption occurred in $10.1 \%$ of subjects and almost only in patients with genetic predisposition, with the same frequency in UC and FAP patients.

Key words: food tolerance, lactose, lactase, IPAA, pouch

Received: 06 November, 2018; revised: 22 March, 2019; accepted: 15 April, 2019; available on-line: 28 May, 2019

⿶e-mail: jarwalk@ump.edu.pl

Abbreviations: BMI, body mass index; FAP, familial adenomatous polyposis; HMBT, hydrogen-methane breath test; RPC, restorative proctocolectomy; UC, ulcerative colitis

\section{INTRODUCTION}

The general health and nutritional status after restorative proctocolectomy (RPC) remains good in most of the patients (Berndtsson et al., 2011; Coffey et al., 2002; Lerch et al., 1989), however, some of them report food intolerance, including milk and dairy products intolerance (Schmidt et al., 2008). Milk tolerance depends mostly on the presence of lactase in the apical surface of enterocytes in the brush border of the small intestine (Deng et al., 2015). Most of the physicians (80\%) recommend that the RPC patients should restrain from these types of products (Bernstein et al., 1994).

To date, several diagnostic procedures are available to test milk tolerance. The gold standard involves the measurement of breath hydrogen, or preferably hydrogen and methane after lactose loading reflecting colonic fermentation of the nonabsorbed lactose (Lisowska et al., 2008). A genetic predisposition towards adult-type hypolactasia can be excluded by analysis of the $\mathrm{C} / \mathrm{T}_{-13910}$ polymorphism (Enattah et al., 2002). The T allele of that polymorphism is dominant and determines high activity (lactase persistence) in the individual's life-span (Madry et al., 2011).

A previous study had suggested that around 60\% of ulcerative colitis (UC) patients develop subjective milk intolerance in at least 10 years after operative treatment (Schmidt et al., 2008). Self-reported dietary intolerances in the RPC patients with familial adenomatous polyposis (FAP) occur in 20-40\% and diminish to 10\% 10 years postoperatively (Schmidt et al., 2008). The aim of this study was to multi-dimensionally assess the lactose intolerance, lactose malabsorption and genetic predisposition in UC and FAP patients who underwent RPC.

\section{METHODS}

This study included 72 patients, aged 21-80 who had undergone RPC due to UC ( $\mathrm{n}=43,17$ men, 26 women) and FAP ( $\mathrm{n}=29,14$ men, 15 women) (Table 1) The operation procedure was performed in the years of 19792012 at The Department of General and Endocrine Surgery and Gastroenterological Oncology, as well as at the Chair of General and Colorectal Surgery of the Poznań University of Medical Sciences, Poland. The inclusion criteria were as follows: RPC, age $\geq 18$, time since ileal pouch-anal anastomosis $\geq 1$ year. Exclusion criteria were: pouchitis, antibiotic therapy within the preceding month, other gastrointestinal conditions.

Lactose intolerance was defined as exhibition of specific clinical symptoms (such as nausea, abdominal distension, abdominal pain, cramps, flatulence, diarrhea or flatus). Lactose malabsorption was assessed by the gold standard hydrogen-methane breath test (HMBT) with the use of QuinTron MicroLyzer DP Plus (QuinTron Instrument Technology, USA). Patients were instructed to avoid ingesting products such as beans and similar vegetables, brans or high-fiber cereals the day before the test. Patients ingested $25 \mathrm{~g}$ of lactose dissolved in $250 \mathrm{ml}$ of water. Hydrogen and methane concentrations in the exhaled breath were assessed at the baseline (at least 12hour fasting) and at half an hour intervals for 3 hours. A positive result indicating lactose intolerance was assessed when the hydrogen level differed by $\geq 20 \mathrm{ppm}$ from the baseline level and/or methane level differed by $12 \mathrm{ppm}$ from the baseline.

Genetic predisposition to lactose intolerance was assessed by detecting the common $-13910 \mathrm{~T} / \mathrm{C}$ polymorphism in the promoter region of the lactase gene with the use of sequence-specific primer PCR and the Mu- 
taGEL Lactase assay (Immundiagnostik AG, Bensheim, Germany).

Comparison between groups has been evaluated with $\mathrm{chi}^{2}$ test and in case of values below 10, the $\mathrm{chi}^{2}$ test with Yates correction. Statistical analysis was performed using STATISTICA 10.0 (StatSoft Inc., Tulsa, USA) and MedCalc 14.8.1. The level of significance was set at $p<0.05$.

\section{Ethical considerations}

This study has been performed in accordance with the ethical standards of Helsinki Declaration and its later amendments. The protocol has been approved by the Bioethical Committee of Poznań University of Medical Sciences (decision 51/11). Three patients did not provide their consent to perform genetic testing.

\section{RESULTS}

Self-reported lactose intolerance was more frequent in the UC patients than the FAP patients $(77.5 \%$ vs. $55.2 \%, p=0.01)$ (Table $1 \mathrm{~B})$. The $\mathrm{C} / \mathrm{C}$ genotype of the lactase gene was observed in $39.1 \%$ of subjects, with no significant difference between the UC and FAP patients. Lactose malabsorption confirmed with objective HMBT occurred in $10.1 \%$ of the subjects, and almost exclusively in patients with a genetic predisposition, with the same frequency in the UC and FAP groups (Table 1B and 1C). No difference in time after ileostomy closure has been observed between the groups with and without lactose malabsorption, the difference between patients with lactose intolerance and lactose tolerance did not reach the level of significance (Table 2).

\section{DISCUSSION}

Previous studies on lactose intolerance and malabsorption after RPC had either included a small sample sizes, had studied only clinical symptoms or mostly focused on patients operated due to UC. None of the studies conducted so far had analyzed the genetic predisposition to adult-type hypolactasia in the RPC patients. The study presented here is the first to provide an up-to-date status on lactose intolerance, lactose malabsorption and genetic predisposition to adult type hypolactasia among the RPC patients.

The main finding of the present study is that the lactose digestion and absorption disorders confirmed with HMBT occurred in $10.1 \%$ of subjects, and almost exclusively in patients with a genetic predisposition, with the same frequency in the UC and FAP groups. The $\mathrm{C} / \mathrm{C}$ genotype of the lactase gene was observed in $39.1 \%$ of subjects. Our previous study had shown that the genetic predisposition for adult-type hypolactasia in a healthy population has a similar prevalence which accounted for 31.5\% (Mądry et al., 2010). Patients with the $\mathrm{C} / \mathrm{C}$ genotype and lactose tolerance had seemingly longer postoperative courses, therefore we cannot exclude the effect of time on the presence of lactose intolerance.

Our study shows that the UC patients had reported lactose intolerance more frequently. This might be caused by the difference in pathophysiology of these two diseases. The disease course and general status in UC are dramatically different than FAP. A dysbiosis of the gut microbiota, as well as chronic inflammation, are more frequently present in UC than FAP. Also, the 
Table 2. Time after ileostomy closure in patients with the C/C genotype with/without lactose malabsorption and with/without lactose intolerance.

\begin{tabular}{|c|c|c|c|}
\hline & \multicolumn{2}{|l|}{ C/C genotype } & \multirow[b]{2}{*}{$p$ value } \\
\hline & $\begin{array}{l}\text { Positive HMBT } \\
n=6\end{array}$ & $\begin{array}{l}\text { Negative HMBT } \\
n=21\end{array}$ & \\
\hline \multirow[t]{2}{*}{$\begin{array}{l}\text { Time after ileostomy closure }[ \\
\text { Mean } \pm \text { S.D. } \\
\left.\text { Median ( } 1^{\text {st }}-3^{\text {rd }} \text { quartile }\right)\end{array}$} & $\begin{array}{l}6.4 \pm 5.5 \\
5(2-10)\end{array}$ & $\begin{array}{l}9.0 \pm 4.5 \\
11(4-12)\end{array}$ & 0.33 \\
\hline & $\begin{array}{l}\text { Lactose intolerance } \\
n=24\end{array}$ & $\begin{array}{l}\text { Lactose tolerance } \\
n=3\end{array}$ & $p$ value \\
\hline $\begin{array}{l}\text { Time after ileostomy closure [years] } \\
\text { Mean } \pm \text { S.D. } \\
\left.\text { Median ( } 1^{\text {st }}-3^{\text {rd }} \text { quartile }\right)\end{array}$ & $\begin{array}{l}8.1 \pm 4.6 \\
10.5(3.5-12)\end{array}$ & $\begin{array}{l}13 \pm 1.7 \\
14(11-14)\end{array}$ & 0.07 \\
\hline
\end{tabular}

incidence of pouchitis in the UC patients is considerably greater than in the FAP patients, and accounts for $30.1 \%$ vs. $5.5 \%$ (OR 6.44; $p<0.001$ ) (Lovegrove et al., 2006). Furthermore patients with UC present the pouch failure, defined as excision of the ileoanal pouch with the need for permanent stoma construction or abdominoperineal reconstruction, more often (Shin et al., 2008). These observations suggest that the underlying inflammatory pathogenesis associated with this systemic condition may predispose those individuals to more complications, including lactose intolerance.

In a previous report, Lerch et al. had found impairment in the intestine lactose absorption in 2 out of 12 RPC patients (Lerch et al., 1989), whereas in the study of Croagh et al. lactose malabsorption was reported in 4 out of 8 UC patients identified as H2-producers with the lactulose breath test (Croagh et al., 2007). In our study, we used the methane measurement in all patients during HMBT, which allowed us to reliably assess the malabsorption. Schmidt et al. evaluated subjective food intolerances in UC patients before and after proctocolectomy (Schmidt et al., 2008). Milk and milk product intolerance occurred in $66.7 \%$ of patients before proctocolectomy and in $30.6 \%$ post proctocolectomy. The study included only 10 subjects with FAP whose preoperative dietary intolerance was negligible, whereas it occurred in 20$40 \%$ cases after operative treatment and diminished to $10 \%$ in 10 years post RPC (Schmidt et al., 2008).

\section{CONCLUSION}

In the study presented here, lactose intolerance was reported by the majority of RPC patients, including those without a genetic predisposition to adult-type hypolactasia. Lactose intolerance occurred more frequently in patients with RPC operated due to UC. Lactose malabsorption was less frequent and was present almost exclusively in patients with a genetic predisposition.

\section{Conflict of Interest}

The authors declare that they have no conflict of interest.

\section{REFERENCES}

Berndtsson IE, Carlsson EK, Persson EI, Lindholm EA (2011) Long-term adjustment to living with an ileal pouch-anal anastomosis. Dis. Colon Rectum 54: 193-199. https://doi.org/10.1007/ DCR.0b013e3181ff42d8

Bernstein CN, Ament M, Artinian L, Ridgeway J, Shanahan F (1994) Milk tolerance in adults with ulcerative colitis. Am. J. Gastroenterol. 89: 872-877

Coffey JC, Winter DC, Neary P, Murphy A, Redmond HP, Kirwan WO (2002) Quality of life after ileal pouch-anal anastomosis: an evaluation of diet and other factors using the Cleveland Global Quality of Life instrument. Dis. Colon Rectum 45: 30-38

Croagh C, Shepherd SJ, Berryman M, Muir JG, Gibson PR (2007) Pilot study on the effect of reducing dietary FODMAP intake on bowel function in patients without a colon. Inflamm. Bowel Dis. 13: 1522-1528. https://doi.org/10.1002/ibd.20249

Deng Y, Misselwitz B, Dai N, Fox M (2015) Lactose intolerance in adults: biological mechanism and dietary management. Nutrients 7: 8020-8035. https://doi.org/10.3390/ nu7095380

Enattah NS, Sahi T, Savilahti E, Terwilliger JD, Peltonen L, Järvelä I (2002) Identification of a variant associated with adult-type hypolactasia. Nat. Genet. 30: 233-237. https://doi.org/10.1038/ng826

Lerch MM, Braun J, Harder M, Hofstădter F, Schumpelick V, Matern S (1989) Postoperative adaptation of the small intestine after total colectomy and J-pouch-anal anastomosis. Dis. Colon Rectum 32: 600-608.

Lisowska A, Banasiewicz T, Marciniak R, Drews M, Majewski P, Herzig K-H, Walkowiak J (2008) Chronic pouchitis is not related to small intestine bacterial overgrowth. Inflamm. Bowel Dis. 14: 11021104. https://doi.org/10.1002/ibd.20432

Lovegrove RE, Tilney HS, Heriot AG, von Roon AC, Athanasiou T, Church J, Fazio VW, Tekkis PP (2006) A comparison of adverse events and functional outcomes after restorative proctocolectomy for familial adenomatous polyposis and ulcerative colitis. Dis. Colon Rectum 49: 1293-1306. https://doi.org/10.1007/s10350-006-0608-0

Mądry E, Fidler E, Walkowiak J (2010) Lactose intolerance - current state of knowledge. Acta Sci. Pol. Technol. Aliment. 9: 343-350

Mądry E, Lisowska A, Kwiecień J, Marciniak R, Korzon-Burakowska A, Drzymała-Czyż S, Mojs E, Walkowiak J (2010) Adult-type hypolactasia and lactose malabsorption in Poland. Acta Biochim. Pol. 57: $585-588$

Schmidt CM, Wiesenauer CA, Sitzmann JV (2008) Long-term effects on diet after proctocolectomy for ulcerative colitis. Am. J. Surg. 195: 353-357. https://doi.org/10.1016/j.amjsurg.2007.12.023

Shin US, Yu CS, Kim DD, Yoon SN, Kim JC (2008) Risk factors of pouch failure after a restorative proctocolectomy. J. Korean Soc. Coloproctology 24: 252. https://doi.org/10.3393/jksc.2008.24.4.252 